\title{
Czech Automotive Exports in the Context of the Global Economic Downturn from the Perspective of Statistics
}

\author{
Simona Hašková ${ }^{1, *}$ \\ ${ }^{1}$ The Institute of Technology and Business, School of Expertness and Valuation, Okruzni 517/10, 37001 \\ Ceské Budejovice, Czech Republic
}

\begin{abstract}
.
Research background: The global outbreak of the COVID-19 and, as a result, the measures taken fundamentally disrupted the lives of people and economies. Private and public demand, industrial production, supply chains, etc. were affected. Given the severity of these shock changes, it is clear that the European Union will have experienced a severe economic recession.

Purpose of the article: Economists have long pointed to the Czech economy's strong dependence on the automotive industry. Carmakers and a number of companies connected to them have been chained into existential difficulties after COVID-19 outbreak. However, the scenario of redirecting the industry is not real.

Methods: The article maps the declines in the forecast of GDP development in 2020 and 2021 in selected EU countries and statistically evaluates the historical dependence of Czech exports on German car production.

Findings \& Value added: According to predictions, the Czech Republic expects the highest negative deviations in comparison with other EU countries. Reality will show what role a strong dependence on the automotive industry plays in this. The results of the statistics of the previous decade do not confirm the fundamental dependence of Czech exports on German automobile production. As the results indicate, Czech exporters are already diversifying at least in the sense of the target markets. The author raises the question whether the concept of public belief in the importance of supporting Czech carmakers as important producers of GDP on the export side can be the result of a strong lobbying by carmakers.
\end{abstract}

Keywords: global economic recession; Czech exports; automotive industry; GDP; lobbing

*Corresponding author: haskovas@post.cz 
JEL Classification: $O 14 ; F 61 ; F 62$

\section{Introduction}

The global COVID-19 pandemic outbreak and, as a result, the containment measures taken have profoundly disrupted people's lives and the economies. The private and public demand, industrial production, supply chains, labour market, commodity prices, capital flows and foreign trade have been hit. Given the deepness of these shock changes, it is obvious that the European Union has been affected by severe economic recession. The COVID-19 outbreak trigged off a symmetric shock and due to tight economic connections of EU states, the aggregate demand and supply shocks have intensified [1].

A current short time period forecast shows incomplete recovery in most of countries [2]. It is clear that crisis impact and the way the individual EU states get over is going to be very uneven. How well and quickly the countries will pull together relies upon many external and internal factors [3]. There is not only the seriousness of the pandemic spread and the strictness of containment measures in play, but a great role belongs to particular economic exposures and pre-existing conditions as well as the policy responses.

The economic impacts of the current crises have been viewed from two basic levels [4] the level of duration and the level of demand/supply side. For instance, the part time jobs and unemployment rise is expected in the short term occurring mainly on the demand side. Hysteresis occurrence in labour market has a potential of both supply and demand side and persisting in the medium term. Emerging market economy drop as a result of expected difficulties to rise external capital is rather perceived as a short-term effect affecting both the demand and supply side. Reorganization of cross border supply chain is expected from the long term affecting demand and supply side, etc.

As regards the pre-existing conditions, the relationship between the economic cyclicality of the EU countries that accepted euro as their national currency and the efficiency of a monetary union in a situation of a non-existing fiscal stabilization mechanism, limited labor factor mobility and economic heterogeneity of the member states is often discussed (see more in [5-7]).

Another important pre-existing economic condition is the state of dependence and tight linkage to one or a small group of export economies. This economic tightness is typical for the Czech automotive industry towards Germany, which is the subject of this research.

The aim of the article is firstly to map and evaluate the declines in the short-term forecast development of GDP in 2020 and 2021 in the selected EU countries for which the car production is an important industry and a source of GPD and secondly to statistically evaluate the dependence of Czech exports on German car production. In this context (in accordance with the input data of the model) we ask to what extent the Czech Republic's car exports depend on German car sales.

\section{Automotive industry condition - before and after COVID-19}

Economists and politicians have often discussed the strong dependence of the Czech economy on the automotive industry and strong export focus on Germany. This dependence manifests itself most drastically during economic crises. The coronavirus outspread brought a significant decline in the production and car sales, automotive components and technologies. For example, Škoda Auto factory that is understood as the heart of the Czech 
industry stopped all lines. This factory creates on average for about five percent of GDP and accounts approximately 9 percent of exports. Some experts suggest to break out of the vulnerable car industry [8] and give more support to other domestic production and entrepreneurs. However, according to economists, such a scenario is not feasible; it is improbable that the Czech industry will be more radically reoriented in the future [9].

Domestic automotive industry production depends on the development of global markets. The vast majority of manufactured cars are exported; in absolute terms in 2019, export involved 1.3 million passenger cars. The $25 \%$ of passenger cars and $40 \%$ of parts and accessories produced domestically are heading to Germany. The German automotive industrial sector is considered then to be the key market for the Czech car manufacturers.

However, as statistics show, the global car sales in 2019 fell by $4 \%$. The reason can be seen in the EU environmental policy, which makes the car manufacturers to be obliged to fulfil environmental regulations and simultaneously respect the motorists' demands. For instance, the German car industry sector experienced a decrease in production before the COVID outbreak; it dropped by $9.4 \%$ in 2018 mainly due to the implementation of the new and mandatory Worldwide Harmonized Light-Duty Vehicles Test Procedure (WLTP) [10]. This affected the main business partners delivering intermediate inputs (for example, the Czech Republic, Slovak Republic, Hungary, etc.).

Looking back at the statistical sales and new registrations of passenger cars between 2005-2019 (see Fig. 1) we see a slight decrease or stagnation in Europe, Russia and Turkey, and a steeper decline globally from 2017.

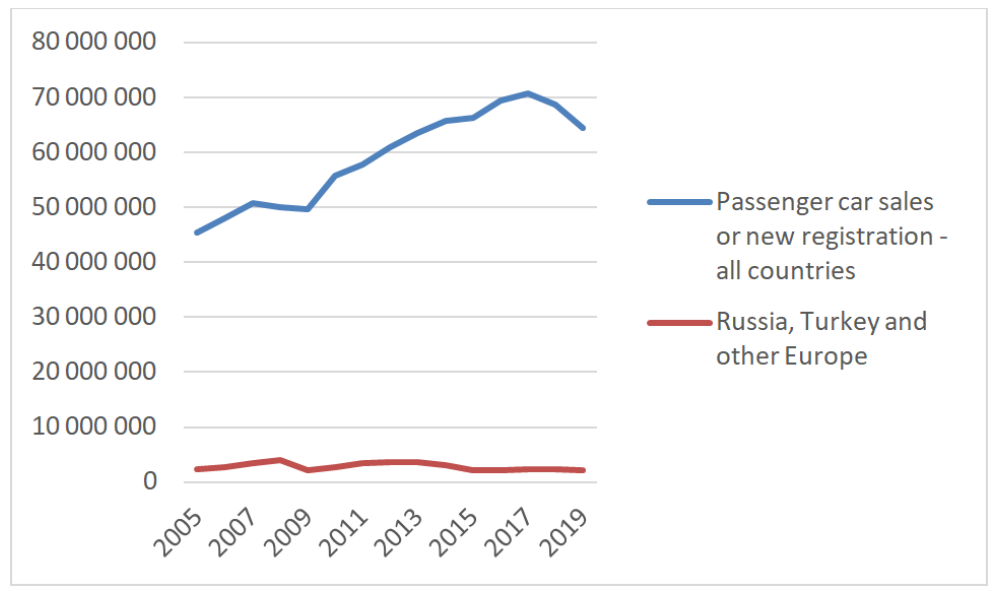

Fig. 1. Statistical sales and new registrations of passenger cars between 2005-2019 Source: [11], author's own processing

The Covid-19 pandemic deepened the problem. The Verband der Automobilindustrie VDA expects the global passenger car market to decrease by $17 \%$ over 2020 as a whole with the most severe decline in Europe. Commercial vehicle markets are expected to be hit even harder.

From the demand side of view the reaction is logical. Why should anyone buy a car now with such uncertainty in the economy? In the first place, redundancies go hand in hand with the economic downturn. Secondly, for many potential customers it is better to postpone their purchase with regard to a possible second wave of the pandemic and restrictions imposed. In addition, there are many quick changes in regulations in terms of ecology that have made 
consumers uncertain and discouraged them from buying a new car. Specifically, from January 2021, a new Euro 6d-ISC-FCM emission standard is to be applied [12] the compliance of which will lead to further price increase. The question arises how car manufacturers should increase the price if demand is already low?

\section{Data and Methodology}

The historical data and statistical predictions have been summarized and analysed for the selected EU countries for 2009-2019 period. The focus was made on the economies where the automotive industry plays a significant role in the overall country's GDP contribution. The data predictions are loaded with limitations due to fundamental uncertainty about the pandemic situation and thus the GDP development. The danger of a protracted recession is real. The point forecasts utilised in this analyses should therefore be understood as just one among several possible scenarios in which assumptions about retreating epidemic and economic recovery are made.

The database involves the manual extraction of historical measures and estimated values of individual parameters related to the automotive industry and macro factors. It is based on the screening of public statistics $([1,12,14])$, national media sources [15], business press and online sources [11].

The statistical analyses applies a functional linear regression, that assumes the linear dependence between two variables - the pairs $\left(X_{i}, Y_{i}\right)$, which are generated by the model $Y_{i}=$ $a+b X_{i}+\varepsilon_{i}$. The $X_{\mathrm{i}}$ are random functions, the intercept $a$ and the errors $\varepsilon_{i}$ are scalars and the slope $b$ is a function [13]. The coefficients of determination $\mathrm{R}^{2}$ (see Fig. 1) can be considered as the implementation of statistical relations between the examined variables.

\section{Results and discussion}

The economic decline is generally associated with the COVID-19 pandemic outbreak. What contributes to the steepness and length of the fall is an unhealthy structure of industry, in which one sector dominates. In the Czech Republic (CZ) the pandemic has only exacerbated the unhealthy macroeconomic trends of the past. Last year Czech industry fell by $0.5 \%$, and in the last quarter of 2019 alone, it fell by $2.3 \%$ [14]. This is evidenced by the fact that the German economy was also declining quarter on quarter at the end of 2019.

The prediction of further economic development is loaded by many uncertainties. Yet, statisticians reveal their point estimates that are utilized as follows: the point forecasts of a year-to-year deviations of GDP (\%) are captured in Fig. 3 [15]. A next year prediction of downfall 2019-2020 and the subsequent rise 2020-2021 is expected in all selected economies. As shown, the greatest fall in GDP is expected in CZ, the mildest in Germany. The reason is obvious - the yearly GDP raise in CZ in 2019 achieved 2,6\%, which was the highest result among the selected countries; e.g., in Germany it was only $0,6 \%$. 


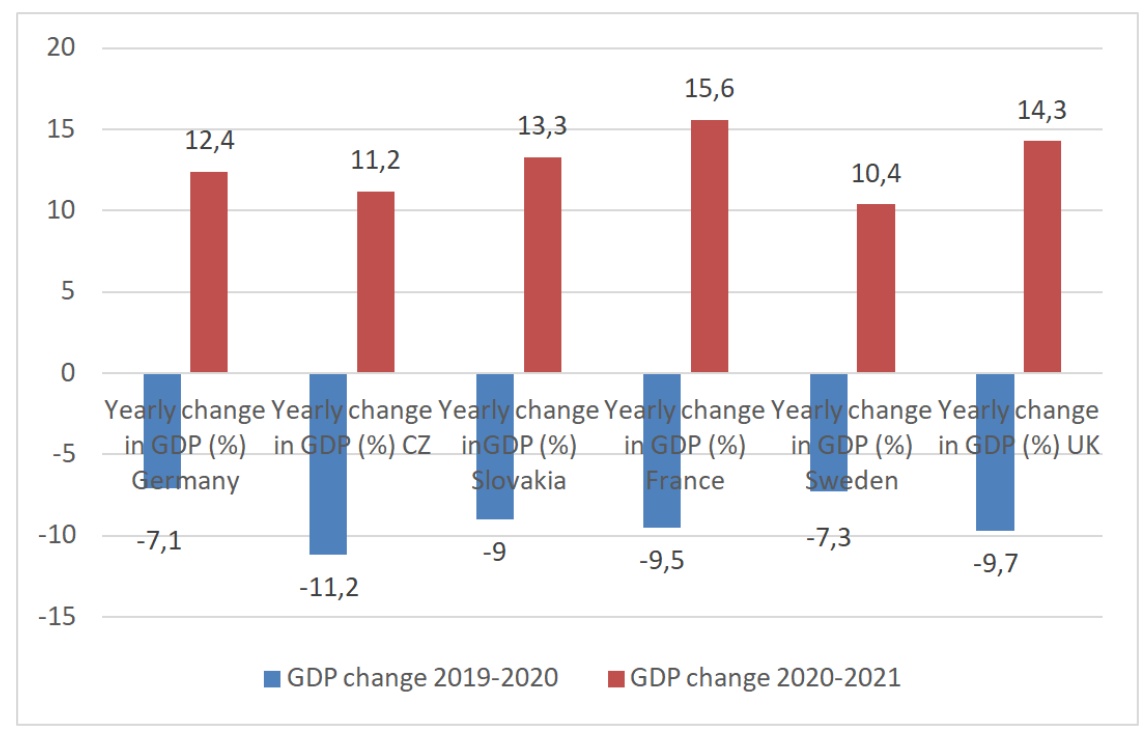

Fig. 2. Prediction of GDP change in \% between 2019-2020 and 2020-2021 Source: [12], author's own processing

Considering the fact that Germany has been the most important trade partner with the share of $31.6 \%$ goods exported on average we further look into the extend of dependence of Czech exports on German car production. This is captured by Fig. 3 describing the behaviour of Czech exports to Germany based on their car production. The mildly negative trend is mainly influenced by the results of period 2016-2018, when German car production was continuously in decline. On the other hand, Czech exports to Germany have risen (20152018) or declined at a slower rate than the decline in German production (2019).

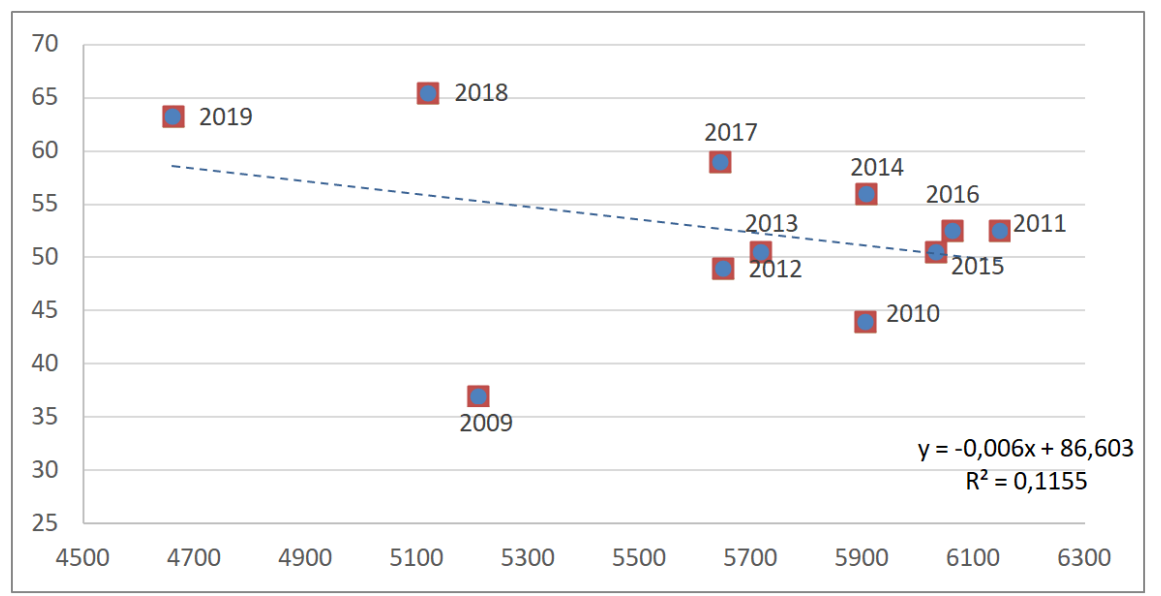

Fig. 3. Reactions of the CZ exports to Germany (in billions USD) based on the German car production (in thousands units)

Source: [15], author's own processing 
The composition of exports from CZ to Germany in 2019 to automotive sector included maximum $26 \%$ share of all exports to Germany; the majority of exported goods then went to other sectors and was produced by a variety of private companies not included in Czech dominant automotive factories. This differentiation of products aiming to the Czech main partner seems to be a trend of the past several years.

The driving force of changes in export policy might have been driven by the past economic crisis 2009 that had serious but diversely extensive effects on individual economies. Most of the countries were affected with high debt, decreasing GDP, increasing unemployment. Domestic consumption, production and investment activities dropped. Due to the dependence of Czech automotive sector on German sector, exports fall dramatically having deprived Czech economy of significant source of income.

Nevertheless, the existence of long-term Czech automotive tradition, the ability to compete on a global level, the large concentration of automotive production, research and development makes this sector a strong industrial player utilising tools and political strategies, such as lobbying, to strengthen its market position. This sector, for instance, has currently advocated for measures to launch guarantees for commercial loans for large companies and to adjust VAT (VW lobbyist Martin Jahn advocated re-introduction of "scrapping" [16]).

However, it is clear that it is mainly the development of car industry in Germany, which is crucial for prosperity of $\mathrm{CZ}$ automotive industry. The current stronger support from the German government has only been applied to electric cars. As a part of the new stimulus package, the government raised the subsidy for the purchase of an electric car from the original three thousand to six thousand euros. Scrapping was advocated by car lobbists to boost demand and help to get old cars with high emissions off the roads. Srapping, however, was not economically supported as its positive effects after the 2008 financial crisis has not been demonstrated in many respects.

In accordance with ecological doctrine, the German automotive industry is undergoing a technological paradigm shift, as electric engines are gradually replacing the combustion engine technology. This transition will make parts of the existing automotive supply chain redundant (more to this topic in [17] - [20]). The COVID-19 pandemic seems to accelerate the transition to this new technology $([21,22])$.

\section{Conclusive remarks}

The paper reflects the changes in economic situation after COVID-19 pandemic outbreak. The special focus was made on the Czech automotive industry and its long-term dependance on the German car sector. This Europe's largest economy has stagnated since summer 2019, which is a state sensitive to any major external stimulus. Before COVID-19 there was a risk of adverse developments as a result of problems in Italy, Brexit, trade wars, futher drop of demand for cars in China, etc. The slowdown of the German economy is contributed to some extend to automotive industry. The ecological doctrines stopped the sale of new cars in 2018 at one point, which is a result of both the campaign against diesel cars and the introduction of new certificates and regulations. This alone showed vulnerability of this sector. The coronavirus pandemic severely weakened automotive industry. The factories were closed for some time; however, the main problem is demand - European customers face financial uncertainty and spending on cars was posponed. This situation reflected in the $\mathrm{CZ}$ car market. 
The developement of economies with significant automotive production were examined in terms of predictions of GDP yearly changes in 2020 and 2021. All the selected economies followed the same trend - severe downfall in 2020, the recovery and product growth in 2021 - these results lean on data predictions assuming the pandemic retreat and the return of economies to normal, which is one of the possible scenarios of future development.

Furthermore, the data were used to evaluate the historical dependence of Czech exports on German car production. The regression trend did not confirm the fundamental dependence of Czech exports on German automobile production. The composition of exporting products to Germany suggests that Czech exports have been already diversified at least in the sense of the target markets. This signals a good direction in the field of export policy towards Germany. Nevertheless, the existence of long-term Czech automotive tradition, the ability to compete on a global level, the large concentration of automotive production in our territory, large car factories with many job opportunities, etc. makes this sector a strong industrial player, which utilises tools and political strategies, such as lobbying, to strengthen its market position. The public belief in the importance of supporting Czech big carmakers as significant contributors to GDP is noticable and to some extend results from a strong lobbying, marketing moves and public relations of large $\mathrm{CZ}$ car producers.

\section{References}

1. Bigio, S., La'o, J. (2020). Distortions in production networks. The Quarterly Journal of Economics, 135(4), 2187-2253.

2. Eurostat (2020). Newsrelease - euro indicators. Retrieved from: https://ec.europa.eu/eurostat/documents/2995521/10294804/4-13052020-AP-

EN.pdf/dfa765ad-4a32-8135-f98f-69e565347750

3. Evgenidis, A., Papadamou, S., Siriopoulos, C. (2020). The yield spread's ability to forecast economic activity: What have we learned after 30 years of studies?. Journal of Business Research, 106, 221-232.

4. del Rio-Chanona, R. M., Mealy, P., Pichler, A., Lafond, F., Farmer, D. (2020). Supply and demand shocks in the COVID-19 pandemic: An industry and occupation perspective. Retrieved from: arXiv preprint arXiv:2004.06759

5. Montani, G. (2011). Money and Finance as Global Public Goods: Contribution to a Supranational Macroeconomic Theory. Sage Open, 1(3), Art. No. 215824401142417.

6. Collignon, S. (2013). Macroeconomic imbalances and competitiveness in the Euro Area. Transfer: European Review of Labour and Research, 19(1), 63-87.

7. Hašková, S., Vochozka, M. (2018). Duality in Cyclical Trends in European Union Confirmed. SAGE Open, 8(1), Art. No. 2158244017753268.

8. Gasiorek, M., Serwicka, I., Smith, A. (2018). Which manufacturing sectors are most vulnerable to Brexit? World Economy, 42(1), 21-56.

9. Srivastava, M., Tyll, L. (2020). The effect of industry-specific networking behaviour on the internationalization performance of Czech SMEs. European Business Review, Early Access: Jun 2020.

10. Leal, J., Lehmann, R., Marc, B., Wollmershäuser, T., Wozniak, P. (2019). The Weakness of the German Car Industry and its Sectoral and Global Impacts. EconPol Policy Brief, 18(3), 1-10. 
11. OICA. (2020). Sales statistics 2005-2015. Retrieved from: http://www.oica.net/category/sales-statistics/

12. European Economic Forecast. Institutional Paper. (2020, May). Retrieved from: https://ec.europa.eu/info/sites/info/files/economy-finance/ip125_en.pdf

13. Hall, P., Horowitz, J. L. (2007). Methodology and convergence rates for functional linear regression. The Annals of Statistics, 35(1), 70-91.

14. Český statistický úřad (2020). Průmysl, energetika. Retrieved from: https://www.czso.cz/csu/czso/prumysl_energetika

15. Trading Economics (2020). Czech Republic exports to Germany. Retrieved from: https://tradingeconomics.com/czech-republic/exports/germany

16. Schwabe, J. (2020). Risk and counter-strategies: The impact of electric mobility on German automotive suppliers. Geoforum, 110, 157-167.

17. Künle, E., Minke, C. (2020). Macro-environmental comparative analysis of e-mobility adoption pathways in France, Germany and Norway. Transport Policy.

18. Sioshansi, F., Webb, J. (2019). Transitioning from conventional to electric vehicles: The effect of cost and environmental drivers on peak oil demand. Economic Analysis and Policy, 61, 7-15.

19. Ketchen Jr, D. J., Craighead, C. W. (2020). Research at the Intersection of Entrepreneurship, Supply Chain Management, and Strategic Management: Opportunities Highlighted by COVID-19. Journal of Management, 46(8), 1330-1341.

20. El Nayal, O., van Oosterhout, J., van Essen, M. (2019). Ties that bind and grind? Investor reactions to politician appointments to corporate boards. Journal of Management.

21. Berger, D., Dew-Becker, I., Giglio, S. (2020). Uncertainty shocks as second-moment news shocks. The Review of Economic Studies, 87(1), 40-76.

22. Jerzmanowski, M. (2017). Finance and sources of growth: evidence from the US states. Journal of Economic Growth, 22(1), 97-122. 